KOMPARTEMEN: JURNAL ILMIAH AKUNTANSI

September 2021, Volume 19 No 2, 121-135

\title{
PENGARUH UKURAN PERUSAHAAN, LEVERAGE, DAN PROFITABILITAS TERHADAP EARNINGS RESPONSE COEFFICIENT \\ (Studi pada Perusahaan Properti dan Real Estate yang Terdaftar di BEI periode 2014-2018)
}

\author{
Yuniar Sarahwati, Iwan Setiadi \\ Institut Teknologi dan Bisnis Ahmad Dahlan Jakarta \\ yuniarsarah76@gmail.com
}

\begin{abstract}
This research was conducted at property and real estate companies listed on the Indonesia Stock Exchange period 2014-2018. The sample was determined using purposive sampling method. The samples obtained was 30 companies with 150 observations. The data analysis method used is multiple linear regression analysis. The results of this study indicate that simultaneously company size, leverage and profitability have a significant effect on the earning response coefficient. While partially proves that firm size has no effect on earnings response coefficients, leverage has a significant negative effect on earnings response coefficients and profitability has a significant positive effect on earnings response coefficients. This research is expected to be useful for investors.
\end{abstract}

Keywords: Firm size, leverage, profitability, earnings response coefficient

\begin{abstract}
ABSTRAK
Penelitian ini dilakukan pada perusahaan property dan real estate yang terdaftar di Bursa Efek Indonesia periode 2014-2018. Sampel ditentukan dengan menggunakan metode purposive sampling. Sampel yang diperoleh sebanyak 30 perusahaan dengan 150 data observasi. Metode analisis data yang digunakan adalah analisis regresi linier berganda. Hasil penelitian ini menunjukkan bahwa secara simultan ukuran perusahaan, leverage dan profitabilitas berpengaruh terhadap earning response coefficient. Sedangkan secara parsial membuktikan bahwa ukuran perusahaan tidak berpengaruh terhadap earning response coefficient, leverage berpengaruh negatif terhadap earning response coefficient dan profitabilitas berpengaruh positif terhadap earning response coefficient. Penelitian ini diharapkan dapat bermanfaat bagi investor.
\end{abstract}

Kata Kunci: Ukuran perusahaan, leverage, profitabilitas, earning response coefficient 


\section{PENDAHULUAN}

Laporan keuangan merupakan suatu hal yang harus ada di dalam perusahaan, karena laporan keuangan adalah tempat untuk mendapatkan informasi yang mencakup semua aktivitas dan kegiatan perusahaan. Dalam laporan keuangan informasi mengenai laba adalah hal yang paling diperhatikan oleh para investor untuk mengatahu berapa besar laba yang di peroleh perusahaan tersebut dalam satu periode, maka laporan laba rugi adalah laporan yang paling diperhatikan oleh investor (Adriani, 2012).

Menurut Suwardjono (2014) dalam (Natsir, 2018), Bagi pelaku pasar untuk mengambil sebuah keputusan dibutuhkan keterbukaan informasi. Reaksi pasar merupakan keputusan pelaku pasar yang dasarnya dilihat dari tindakan 2 pelaku pasar dan reaksi pasar dapat dipicu dari informasi laba perusahaan. Reaksi pasar bisa di lihat dari pergerakaan saham perusahaan saat dimana perusahaan mengumumkan laba perusahaan pada pasar modal.

Menurut Wulandari dan Herkulanus (2015), earning respons coefficient (ERC) merupakan cara yang kerap dipakai buat menilai kualitas laba. Kualitas laba dindikasikan dengan kuatnya reaksi pasar mengenai infomasi laba yang terlihat melalui tingginya ERC. Bertambah tinggi ERC hinga makin tinggi pula informasi keuntungan yang didapat untuk melakukan kepastian investasi. Sebaliknya, bertambah rendah ERC, maka bertambah rendah pula data laba yang didapat untuk membuat keputusan, sehingga menyebabkan investor sulit untuk memperkirakan laba yang akan diperoleh dari pendanan saham terhadap suatu perusahaan di masa yang akan datang.

Penelitian ini didasari dengan adanya fenomena tentang peningkatan laba perusahan yang tidak selalu disertai dengan peningkatan harga saham dan begitu juga sebaliknya. Tahun 2014 PT Agung Podomoro Land Tbk memperoleh laba Rp983.875.368.000 dan meningkat pada tahun 2015 menjadi Rp1.118.073.171.000. Peningkatan laba justru diikuti dengan penurunan harga saham dari Rp335 menjadi Rp334 per lembar saham. Tahun 2016 laba diperoleh sebesar Rp961.076.999.000 dan mengalami penurunan dari tahun 2015 dan harga saham juga turun dari harga Rp334 menjadi Rp210 per-lembar. Laba yang diperoleh tahun 2017 mengalami kenaikan dari tahun 2016 menjadi Rp1.871.892.833.000 sedangkan harga saham tetap pada Rp210 per lembar. Sedangkan laba yang di peroleh tahun 2018 mengalami penurunan dari tahun 2017 menjadi Rp248.210.474.000 dan harga saham mengalami penurunan harga dari Rp210 jadi Rp152 per lembar (https://finance.yahoo.com, 2018).

Tahun 2014 PT Alam Sutera Realty Tbk memperoleh laba sebesar Rp1.176.955.123.000 dan mengalami penurunan pada tahun 2015 menjadi Rp686.484.951.000 
dikuti dengan penurunan harga saham dari awalnya Rp560 per-lembar menjadi Rp343 per lembar. Pada tahun 2016 laba yang di peroleh Rp520.649.362.000 dimana ini terjadi penurunan dari tahun 2015 sedangkah harga saham mengalami peningkatan dari Rp 343 menjadi Rp 352 per-lembar sahamnya. Pada tahun 2017 laba perusahaan mengalami peningkatan dari 2016 menjadi Rp1.377.949.750.000 dan mengalami peningkatan pada harga saham dari Rp352 menjadi Rp356. Pada tahun 2018 laba yang diperoleh sebesar Rp978.665.528.000 dimana ini mengalami penurunan dari tahun 2017 dan harga saham juga mengalami penurunan dari Rp356 menjadi Rp312 per-lembar (https://finance.yahoo.com, 2018). Melalui penjelasan di atas menunjukkan bahwa peningkatan laba perusahan tidak selalu disertai dengan peningkatan harga saham dan sebaliknya jika terjadi penurunan laba perusahan tidak harus selalu disertai dengan penurunan harga saham. Fenomena tersebut menjadi perhatian khusus investor karena ketidakstabilan harga saham. Fenomena naik ataupun turunnya harga saham dalam pasar modal mengakibatkan investor harus lebih telaah dan memilih mana saham yang dapat memberikan keuntungan atau return yang terbaik dan risiko terkecil dalam berinvestasi (Oktavianna Sembiring, 2015).

Penelitian yang membahas tentang ERC sudah banyak diteliti oleh beberapa peneliti sebelumnya. Setiawati dkk (2014) menyimpulkan bahwa ukuran perusahaan dan profitabilitas berpengaruh terhadap ERC. Syahnal (2018) menyimpulkan leverage berpengaruh positif terhadap ERC. Herdirinandasari dan Asyik (2016), Setiawati dkk (2014), Mahendra dan Wirama (2017) juga menyimpulkan profitabilitas berpengaruh terhadap ERC. Agung dan Pande (2017) menunjukkan bahwa leverage berpengaruh negatif terhadap ERC. Adapun Wahyudi dan Kadir (2019) menemukan bahwa ukuran perusahaan tidak memiliki pengaruh terhadap ERC.

Hasil penelitian tersebut menemukan hasil yang tidak konsisten. Penelitian ini bertujuan membuktikan secara empiris pengaruh ukuran perusahaan, leverage dan profitabilitas terhadap ERC. Penelitian ini menggunakan sampel sektor perusahaan properti dan real estate dengan jangka waktu tahun 2014-2018. Rentang waktu observasi harga saham selama 5 hari sebelum dan sesudah tanggal pengumuman laporan keuangan.

\section{LITERATURE REVIEW}

\section{Earning response coefficient}

Menurut Rahmawati (2016) dalam Merlin (2018), koefisien respon laba digunakan untuk mengukur seberapa kokoh saham abnormal memberikan reaksi faktor laba yang tidak terduga yang dilaporkan perusahaan dari penerbitan saham. Koefisien respon laba atau ERC bermanfaat 
dalam analisis untuk menghitung nilai saham sesungguhnya. Informasi keuangan perusahaan menjadi dasar evaluasi para investor dalam memastikan respon pasar, berdasarkan data laba/keuntungan didalam return saham. ERC kerap digunakan buat memantau pertumbuhan ataupun perkembangan sesuatu perusahaan serta bisa pula digunakan buat memperhitungkan dari risiko saham serta earnings per-share (Sandi, 2013).

\section{Pengaruh ukuran perusahaan terhadap earning response coefficient}

Berdasarkan ukurannya, perusahaan bisa dibedakan menjadi dua kategori yakni perusahaan besar dan perusahaan kecil. Perusahaan besar memiliki laba yang lebih berkembang dan berdampak pada besarnya respon pasar terhadap return saham. Investor lebih suka sama perusahaan yang ukuran besar dari pada perusahaan ukuran kecil, karena Sehingga besarnya ukuran perusahaan berpengaruh positif terhadap earning response coefficient. Hal ini didukung oleh Herdirinandasari dan Asyik (2016) yang menyatakan bahwa ukuran perusahaan mempunyai pengaruh positif terhadap ERC. Berdasarkan penjelasan diatas maka dirumuskan hipotesis:

\section{H1 : Ukuran perusahaan berpengaruh positif terhadap Earnings Response Coefficient}

\section{Pengaruh leverage terhadap earning response coefficient}

Leverage adalah rasio yang menilai atau memperkirakan sebesar apa perusahaan dibiayai dengan hutang. Menurut Harahap (2013) dalam (Natsir, 2018), leverage merupakan rasio antara utang perusahaan atas modal. Leverage digunakan untuk melihat seberapa tinggi rasio sumber pendanaan perusahaan yang berasal dari hutang atau pihak eksternal dibandingkan dengan modal sendiri. Menurut Merlin (2018), tingkat hutang perusahaan dapat memberikan pengaruh kepada kualitas laba yang diperoleh. Perusahaan dengan jumlah hutang besar seringkali menghasilkan kualitas dan mutu laba yang rendah.

Perusahaan dengan tingkat leverage tinggi, menyebabkan kewajiban perusahaan membayar hutang kepada kreditur lebih tinggi disbanding membayar deviden. Hal ini berakibat pada reaksi pasar menjadi rendah. Dewi dan Putra (2017) menyimpulkan bahwa leverage berpengaruh negatif terhadap ERC. Berdasarkan hal tersebut, dapat dirumuskan hipotesis seperti berikut:

\section{$\mathrm{H}_{2}$ : Leverage berpengaruh negatif terhadap earnings response coefficient}

Pengaruh profitabilitas terhadap earning response coefficient 
Profitabilitas adalah kemampuan perusahaan untuk mendapatkan hasil laba atau profit. Perusahaan dengan tingkat profitabilitas tinggi cenderung mengungkapkan laba mereka. Investor cenderung merespon informasi tersebut dengan cepat karena laba dianggap menguntungkan dalam pembagian deviden. Besarnya respon investor dalam menanggapi laba juga akan berdampak pada tingginya nilai ERC suatu perusahaan (Dewi dan Yadnyana, 2019). Herdirinandasari dan Asyik (2016) juga menemukan bahwa profitabilitas berpengaruh positif terhadap ERC. Tingginya tingkat profitabilitas meningkatkan tingkat pengungkapan mereka. Hal ini menyebabkan tingginya respon/reaksi investor. Semakin tinggi respon investor maka ERC yang diperoleh juga makin tinggi (Nikmah, 2018). Berdasarkan penjelasan tersebut, dirumuskan hipotesis seperti berikut:

\section{H3: Profitabilitas berpengaruh positif terhadap earning response coefficient}

\section{H4: Ukuran perusahaan, leverage dan profitabilitas berpengaruh simultan terhadap earnings response coefficient}

Berdasarkan penjelasan dan pengambangan hipotesis tersebut, kerangka pemikiran penelitian digambarkan pada Gambar 1.

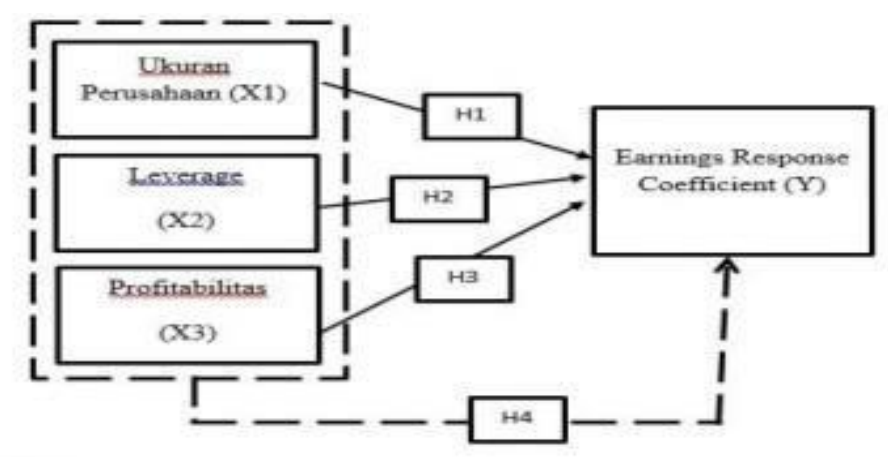

Keterangan:

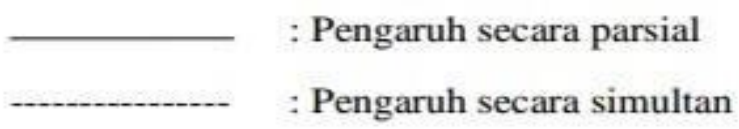

Gambar 1. Kerangka pemikiran penelitian

\section{METODE PENELITIAN}

Pengambilan sampel menggunakan metode purposive sampling, yaitu dilakukan dengan mengambil sampel dari populasi berdasarkan suatu kriteria tertentu yaitu perusahaan properti dan real estate yang terdaftar di Bursa Efek Indonesia (BEI) periode 2014-2018 serta memiliki data laporan tahunan dan laporan keungan lengkap, perusahaan menggunakan mata uang rupiah, perusahaan tidak mengalami kerugian selama periode masa penelitian, serta 
mempublikasi harga saham harian. Populasi yang digunakan berjumlah 70 perusahaan, setelah dilakukan seleksi pemilihan sampel sesuai kriteria yang telah ditentukan, maka diperoleh 30 perusahaan yang memenuhi kriteria sampel. Periode yang digunakan selama 5 tahun sehingga jumlah data amatan sebanyak 150 sampel. Metode pengumpulan data yang digunakan dalam penelitian ini berupa data sekunder, data sekunder diperoleh dari laporan keuangan perusahaan perusahaan yang diperoleh dari database yang tersedia di situs Bursa Efek Indonesia (www.idx.co.id).

Ukuran perusahaan diproksikan dengan logaritma natural (Ln) total aset. Leverage diproksikan menggunakan Debt to Asset Ratio (DAR). DAR adalah rasio total hutang terhadap total aset. Profitabilitas diproksikan dengan Return on Assets (ROA) yang merupakan rasio laba setelah pajak terhadap total aset. Untuk menentukan besarnya earnings response coefficient menggunakan perhitungan cumulative abnormal return (CAR) dan unexpected earnings (UE) (Natsir, 2018).

\section{HASIL PENELITIAN DAN PEMBAHASAN}

Tabel.1 memberikan gambaran statistik deskriptif dari setiap variabel khususnya minimum, maksimum, rata-rata, standar deviasi, dan jumlah pengamatan.

Tabel 1. Statistik Deskriptif

\begin{tabular}{|l|r|r|r|r|r|}
\hline & \multicolumn{7}{|c|}{ Descriptive Statistics } \\
\hline & $\mathrm{N}$ & Minimum & Maximum & \multicolumn{1}{c|}{ Mean } & \multicolumn{1}{c|}{$\begin{array}{c}\text { Std. } \\
\text { Deviation }\end{array}$} \\
\hline Ukuran perusahaan & 150 & 25.87 & 31.67 & 29.3589 & 1.29148 \\
Leverage & 150 & .06 & .79 & .3894 & .15893 \\
ROA & 150 & .00 & .36 & .0633 & .05784 \\
ERC & 150 & -.06 & .31 & .0413 & .08027 \\
Valid N (listwise) & 150 & & & & \\
\hline
\end{tabular}

Sumber: Data diolah, 2020

Variabel ukuran perusahaan memiliki nilai minimum sebesar 25,87 dan nilai maksimum sebesar 31,67. Nilai rata - rata (mean) variabel ukuran perusahaan menunjukkan ukuran perusahaan yang dilihat dari total aset perusahaan property dan real estate tinggi. Variabel leverage memiliki nilai minimum sebesar 0,06 dan nilai maksimum sebesar 0,79 . Nilai rata rata (mean) variabel leverage menunjukkan rasio hutang terhadap modal sendiri sebesar 0,3894 $(38,94 \%)$.

Variabel ROA yang menggambarkan profitabilitas memiliki nilai minimum sangat kecil $(0,000026)$ dan nilai maksimum sebesar 0,36 . Nilai rata - rata (mean) variabel profitabilitas 
menunjukkan tingkat keuntungan yang dihasilkan perusahaan property dan real estate sebesar 0,0632 (6,32\%). Variabel ERC memiliki nilai minimum sebesar -0,06 dan maksimum sebesar 0,31 . Nilai rata - rata (mean) variabel ERC adalah 0,0413 .

\section{Uji Normalitas}

Uji normalitas dalam penelitian ini dilakukan dengan grafik normal probability plot. Model regresi yang dilakukan dikatakan berdistribusi normal bila data menyebar disekitar garis diagonal dan penyebarannya mengikuti dan mendekati arah garis diagonal. Berikut ini merupakan hasil uji normalitas menggunakan uji grafik normal probability plot.

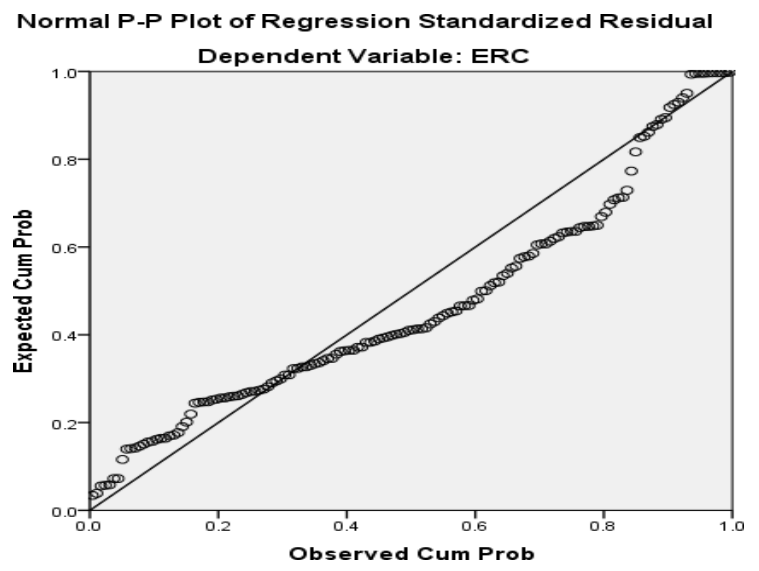

Gambar 2 Grafik Normal Probability plot

Berdasarkan pada Gambar 2 bahwa data menyebar di sekitar garis diagonal dan penyebarannya mengikuti dan mendekati arah garis diagonal. Hal ini menunjukkan bahwa data dalam penelitian ini berdistribusi normal, sehingga dapat disimpulkan bahwa model regresi ini memenuhi asumsi normalitas.

\section{Uji Multikolinearitas}

Pengujian multikolinearitas menggunakan nilai tolerance dan VIF (Variance Inflation Factor). Apabila nilai tolerance $>0,1$ dan VIF $<10$ maka dapat disimpulkan data bebas dari gejala multikolinieritas (Ghozali, 2013) dalam Natsir (2018). 
Tabel 2. Hasil Uji Multikolinearitas

\begin{tabular}{|c|c|c|c|c|c|c|c|c|}
\hline \multicolumn{9}{|c|}{ Coefficients $^{\mathrm{a}}$} \\
\hline \multirow[b]{2}{*}{ Model } & & \multicolumn{2}{|c|}{ Unstandardized Coefficients } & \multirow{2}{*}{$\begin{array}{c}\begin{array}{c}\text { Standardized } \\
\text { Coefficients }\end{array} \\
\text { Beta }\end{array}$} & \multirow[b]{2}{*}{$t$} & \multirow[b]{2}{*}{ Sig. } & \multicolumn{2}{|c|}{ Collinearity Statistics } \\
\hline & & $B$ & Std. Error & & & & \begin{tabular}{|l} 
Tolerance \\
\end{tabular} & VIF \\
\hline \multirow[t]{4}{*}{1} & (Constant) & -.833 & .474 & & -1.756 & .081 & & \\
\hline & Ukuran perusahaan & .242 & .139 & .148 & 1.740 & .084 & .845 & 1.184 \\
\hline & Leverage & -.038 & .012 & -.277 & -3.223 & .002 & .833 & 1.200 \\
\hline & ROA & .220 & .110 & .158 & 1.997 & .048 & .983 & 1.018 \\
\hline
\end{tabular}

a. Dependent Variable: ERC

Sumber: Data diolah, 2020

Berdasarkan Tabel 2. menunjukkan nilai VIF dan tolerance variabel ukuran perusahaan, leverage dan ROA seluruhnya $<10$ dan $>0,1$. Hal ini berarti model regresi tidak mengandung gejala multikolinearitas.

\section{Uji Autokorelasi}

Uji autokorelasi bertujuan untuk menguji apakah dalam model regresi linier ada korelasi antara kesalahan pengganggu pada periode $\mathrm{t}$ dengan kesalahan pengganggu pada periode sebelumnya t-1 (Ghozali, 2013 dalam Natsir, 2018).

\section{Tabel 3 Hasil Uji Autokorelasi}

\section{Model Summary}

\begin{tabular}{|l|r|r|r|r|r|}
\hline Model & $R$ & R Square & $\begin{array}{c}\text { Adjusted R } \\
\text { Square }\end{array}$ & $\begin{array}{l}\text { Std. Error of } \\
\text { the Estimate }\end{array}$ & $\begin{array}{l}\text { Durbin- } \\
\text { Watson }\end{array}$ \\
\hline 1 & $.320^{\mathrm{a}}$ & .102 & .084 & .06956 & 2.324 \\
\hline
\end{tabular}

a. Predictors: (Constant), ROA, Ukuran perusahaan, Leverage

b. Dependent Variable: ERC

Sumber: Data diolah, 2020

Pada Tabel 3 nilai Durbin-Watson untuk model regresi adalah 2,324. Karena nilai Durbin-Watson dalam penelitian ini tidak kurang dari 1 dan tidak lebih dari 3, yang artinya tidak terjadi autokorelasi.

\section{Uji Heterokedastisitas}

Uji heteroskedastisitas bertujuan menguji apakah dalam model regresi terjadi ketidaksamaan varians dari residual satu pengamatan ke pengamatan yang lain (Ghozali, 2013). Hasil uji heterokedastisitas disajikan pada Gambar 3. 


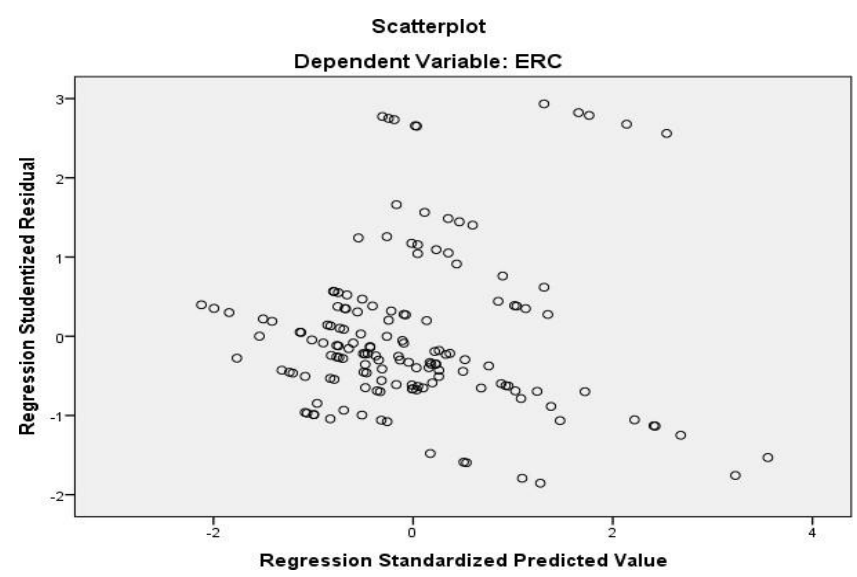

Gambar 3 Hasil Uji Heteroskedastisitas

Dari grafik scatterplot terlihat bahwa titik-titik data yang ada menyebar secara acak tersebar baik diatas maupun dibawah angka 0 pada sumbu Y yang artinya bahwa tidak terjadi heteroskedastisitas.

\section{Analisis Regresi Linear Berganda}

Data dalam penelitian ini diambil dari 150 data amatan. Hasil regresi linier berganda disajikan pada Tabel 4.

Tabel 4. Hasil Analisis Regresi Linear Berganda

\begin{tabular}{|c|c|c|c|c|c|c|c|c|}
\hline \multicolumn{9}{|c|}{ Coefficients $^{a}$} \\
\hline \multirow[b]{2}{*}{ Model } & & \multicolumn{2}{|c|}{ Unstandardized Coefficients } & \multirow{2}{*}{$\begin{array}{c}\text { Standardized } \\
\text { Coefficients }\end{array}$} & \multirow[b]{2}{*}{$t$} & \multirow[b]{2}{*}{ Sig. } & \multicolumn{2}{|c|}{ Collinearity Statistics } \\
\hline & & $B$ & Std. Error & & & & Tolerance & VIF \\
\hline 1 & (Constant) & -.833 & .474 & & -1.756 & .081 & & \\
\hline & Ukuran perusahaan & .242 & .139 & .148 & 1.740 & .084 & .845 & 1.184 \\
\hline & Leverage & -.038 & .012 & -.277 & -3.223 & .002 & .833 & 1.200 \\
\hline & ROA & .220 & .110 & .158 & 1.997 & .048 & .983 & 1.018 \\
\hline
\end{tabular}

a. Dependent Variable: ERC

Sumber: Data diolah, 2020

Berdasarkan Tabel 4, model regresi linear berganda dapat dibuat seperti persamaan (1).

$$
Y=-0,833+0,242 X 1+-0,038 X 2+0,220 X 3+\varepsilon
$$

\section{Uji Statistif F (Uji simultan)}

Uji $\mathrm{F}$ digunakan untuk menguji pengaruh variabel bebas secara bersama-sama (simultan) terhadap variabel terikat (Handayani, 2015). Hasil uji F disajikan pada Tabel 5. 
Tabel 5. Hasil Uji Simultan (Uji F)

ANOVA $^{\mathrm{a}}$

\begin{tabular}{|c|c|c|c|c|c|c|}
\hline \multicolumn{2}{|c|}{ Model } & Sum of Squares & df & Mean Square & $\mathrm{F}$ & Sig. \\
\hline \multirow[t]{3}{*}{1} & Regression & .080 & 3 & .027 & 5.545 & $.001^{t}$ \\
\hline & Residual & .706 & 146 & .005 & & \\
\hline & Total & .787 & 149 & & & \\
\hline
\end{tabular}

a. Dependent Variable: ERC

b. Predictors: (Constant), ROA, Ukuran perusahaan, Leverage

Sumber: Data diolah, 2020

Berdasarkan hasil output diatas diperoleh bahwa nilai signifikan (sig) untuk pengaruh $\mathrm{X} 1, \mathrm{X} 2, \mathrm{X} 3$ secara simultan terhadap Y adalah sebesar $0,001<0,05$, maka dapat disimpulkan bahwa ukuran perusahaan, leverage dan profitabilitas secara simultan berpengaruh terhadap earning response coefficient sehingga $\mathrm{H} 4$ diterima.

\section{Uji Statistik t ( Uji Parsial)}

Menurut Ghozali (2013) dalam (Natsir, 2018), menyatakan bahwa uji t digunakan untuk mengetahui tingkat signifikansi pengaruh variabel bebas terhadap variabel terikat secara individu atau parsial.

\section{Tabel 6 Hasil Uji Parsial (Uji t)}

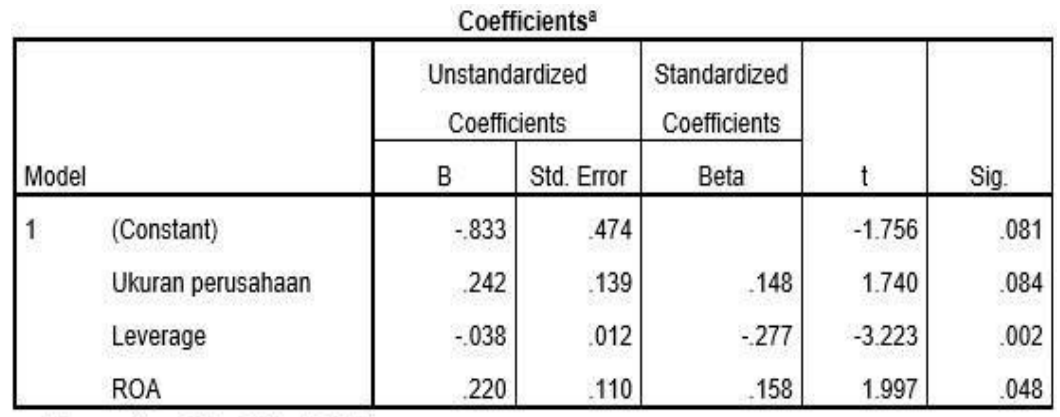

a. Dependent Variable: ERC

Sumber: Data diolah, 2020

Hasil pengujian pengaruh ketiga (3) variabel independen terhadap variabel dependennya adalah sebagai berikut:

a. Berdasarkan tabel 6 nilai signifikansi variabel ukuran perusahaan sebesar 0,84 maka dapat disimpulkan bahwa ukuran perusahaan secara pasial tidak berpengaruh signifikan terhadap earning response coefficient, yang artinya bahwa $\mathrm{H}_{1}$ ditolak.

b. Berdasarkan tabel 6 nilai koefisien regresi leverage sebesar -0,038 yang artinya bahwa leverage memiliki pengaruh negative terhadap earning response coefficient. Leverage menghasilkan nilai signifikansi sebesar 0,002 $(<0,05)$ maka dapat disimpulkan bahwa variabel leverage secara parsial berpengaruh negatif yang signifikan terhadap earning 
response coefficient yang artinya $\mathrm{H}_{2}$ diterima.

c. Berdasarkan tabel 6 profitabilitas menghasilkan nilai signifikansi sebesari 0,048 yang dimana ini lebih kecil dari $0,05(<0,05)$ dan koefisien regresi profitabilitas / ROA sebesar 0,220, dapat disimpulkan bahwa variabel profitabilitas / ROA secara parsial berpengaruh positif yang signifikan terhadap earning response coefficient sehingga $\mathrm{H}_{3}$ diterima.

\section{Uji Koefisien Determinasi $\left(\mathbf{R}^{\mathbf{2}}\right)$}

Koefisien determinan di gunakan buat menlihat berapa besar tingkat pengaruh variabel independen tehadap variabel dependen secara parsial. Koefisien determinan menjelaskaan proporsi variansi didalam variabel dependent yang dijelaskan oleh cuma satu variabel independent (Handayani, 2015).

\section{Tabel 7. Hasil Uji Koefisien Determinasi}

Model Summary
\begin{tabular}{|l|c|c|c|c|c|}
\hline Model & $R$ & R Square & $\begin{array}{c}\text { Adjusted R } \\
\text { Square }\end{array}$ & $\begin{array}{c}\text { Std. Error of } \\
\text { the Estimate }\end{array}$ & $\begin{array}{c}\text { Durbin- } \\
\text { Watson }\end{array}$ \\
\hline 1 & $.320^{\mathrm{a}}$ & .102 & .084 & .06956 & 2.324 \\
\hline
\end{tabular}
a. Predictors: (Constant), ROA, Ukuran perusahaan, Leverage
b. Dependent Variable: ERC

Sumber: Data diolah, 2020

Berdasarkan Tabel 7 menunjukan hasil nilai adjusted $R$-Square sebesar 0,084. Sehingga variabel ukuran perusahan, leverage dan profitabilitas mampu menjelaskan 8,4\% sedangkan sisanya 91,6\% di jelaskan oleh variabel-variabel diluar variabel independen penelitan.

\section{Pengaruh ukuran perusahaan terhadap earning response coefficient}

Hasil dari uji hipotesis menunjukan bahwa nilai signifikansi variabel ukuran perusahaan 0,84> 0,05 yang berarti bahwa ukuran perusahaan tidak berpengaruh terhadap ERC. Hasil penelitian ini tidak sejalan dengan Herdirinandasari dan Asyik (2016) yang menemukan bahwa ukuran perusahaan memiliki pengaruh yang positif terhadap earnings response coefficient. Ukuran perusahaan tidak memiliki pengaruh atas ERC dikarenakan perusahaan besar menyebabkan investor tidak terlalu melihat ukuran suatu perusahan dalam mengambil keputusan investasi. Perusahaan yang telah terdaftar di BEI dianggap telah dewasa dan punya total aset yang tinggi. Sebab itu ukuran perusahaan tidak berpengaruh terhadap ERC. 


\section{Pengaruh leverage terhadap Eearning Response Coefficient}

Kasmir (2012) menyatakan kalau rasio leverage dipakai untuk menilai kesanggupan perusahan buat membayar semua kewajibanya, baik jangka panjang ataupun jangka pendek. Berdasarkan hasil uji hipotesis dikatakan leverage berpengaruh negatif tehadap earnings response coefficient. Maka dapat disimpulkan bahwa investor kurang percaya/tertarik menginvestasikan modal kepada perusahaan yang memiliki leverage tinggi. Perusahan yang memiliki leverage tinggi cenderung mementingkan pembayaran hutang dari pada deviden untuk para pemegang saham. Hasil penelitian ini sejalan atau mendukung Dewi dan Putra (2017) yang menyatakan bahwa leverage berpengaruh negatif pada Earnings Response Coefficient namun hasil ini bertentangan dengan Natsir (2018) dan Arif (2016) bahwa leverage berpengaruh positif terhadap earning response coefficient. Maka dapat disimpulkan bahwa tidak selalu leverage atau hutang yang tinggi dapat membuat perusahaan bangkrut karena banyak perusahaan yang mempunyai leverage yang tinggi dipakai buat menjalankan usahanya yang tujuannya supaya keuntungan yang didapat lebih besar.

\section{Pengaruh Profitabilitas terhadap Eearning Response Coefficient}

Bersumber pada hasil uji hipotesis di ketahui kalau profitabilitas berpengaruh positif terhadap ERC. Perusahaan yang memiliki profitabilitas tinggi maka makin tinggi pula respon investor atas kinerja mereka. Semakin besar respon mereka menyebabkan tingkat ERC yang tinggi juga (Nikmah, 2018).

Hasil penelitian ini sejalan atau mendukung Herdirinandasari dan Asyik (2016) yang menemukan bahwa profitabilitas memiliki pengaruh yang positif terhadap earnings response coefficient. Namun hasil ini bertolak belakang dengan Nyoman dkk (2019), Anggraini (2015) yang menyatakan bahwa profitabilitas memiliki pengaruh negatif terhadap earnings response coefficient, dan Fitri (2013) yang menyatakan bahwa profitabilitas tidak berpengaruh terhadap earning response coefficient.

\section{Pengaruh ukuran perusahaan, leverage dan profitabilitas terhadap earnings response coefficient}

Berdasarkan hasil dari pengujian uji $\mathrm{F}$ nilai signifikansi adalah $0,001<0,05$ sehingga bisa di simpulkan kalau ukuran perusahan, leverage dan profitabilitaas secara simultan bepengaruh signifikan tehadap earning response coefficient. 


\section{KESIMPULAN DAN SARAN}

Berdasarkan hasil analisis yang telah dilakukan, dapat diambil kesimpulan bahwa ukuran perusahan tidak bepengaruh, leverage berpengaruh negatif, profitabilitas berpengaruh positif terhadap earning response coefficient. Ukuran perusahaan, leverage dan profitabilitas secara simultan berpengaruh terhadap earning response coefficient.

Untuk penelitian selanjutnya peneliti menyarankan untuk menambahkan variabel lainnya yang mempunyai pengaruh terhadap ERC diluar dari variabel yang dipakai dalam penelitian ini. Penelitian selanjutnya juga bisa menggunakan sampel perusahaan lainnya yang lebih spesifik dan tahun penelitian yang lebih lama. Bagi manajemen perusahaan yang ingin meningkatkan nilai ERC perusahaan perlu mempertahankan proporsi profitabilitas yang berpengaruh positif dan memperkecil leverage yang memiliki pengaruh negatif terhadap ERC.

\section{Daftar Pustaka}

Adriani, L. (2012) "Pengaruh Ukuran Perusahaan dan Struktur Modal terhadap Earnings Response Coefficient (Studi pada Perusahaan Sektor Manufaktur yang Terdaftar di BEI)", Artikel Ilmiah, pp. 1-15.

Andriani Tisna, G., \& Agustami, S. (2016). "Pengaruh Good Corporate Governance Dan Ukuran Perusahaan Terhadap Kinerja Keuangan Perusahaan (Pada Perusahaan Perbankan Yang Terdaftar Di Bursa Efek Indonesia (Bei) Tahun 2010-2014)." Jurnal Riset Akuntansi Dan Keuangan. Https://Doi.Org/10.17509/Jrak.V4i2.4038

Anggraini, V. (2015) 'Pengaruh Pengungkapan Islamic Social Reporting (Isr), Profitabilitas, Dan Leverage Terhadap Earning Response Coefficient (ERC) (Studi Empiris pada Perusahaan yang Terdaftar di Jakarta Islamic Index Tahun 2010-2013)', Skripsi Universitas Islam Negeri Syarif Hidayatullah Jakarta. doi: 10.1145/3132847.3132886.

Azhari, Muhammad Faiza. (2017). "Pengaruh Self Assessment System Dan Pemeriksaan Pajak Terhadap Tax Evasion (Survey Pada Kpp Madya Bandung, Kpp Pratama Bandung Cibeunying, Kpp Pratama Bandung Cicadas, Kpp Pratama Bandung Tegallega, Dan Kpp Pratama Bandung Bojonagara)". Diss. Fakultas Ekonomi dan Bisnis Unpas Bandung, 2017

Brigham, Eugene F., Joel F. Houston, Hsu Jum-Ming, Kong Yoon Kee, and A.N Bany-Ariffin. (2015). "Essentials of Financial Management". Edited by Lian Siew Han. 3rded. Singapore: Roy Lee

Dewi, A. A. P. K. and Putra, I. M. P. D. (2017) "Pengaruh Leverage Dan Ukuran Perusahaan Pada Earnings Response Coefficient", E-Jurnal Akuntansi.

Field, A. (2009). "Discovering statistics using SPSS". Third edition. Sage. 
Ghozali, I. (2013) 'Analisis Multivariate dengan program IBSM SPSS21',Semarang: Universitas Diponegoro.

Ghozali, I. (2016) "Aplikasi Analisis Multivariate dengan Program IBM SPSS 23",(Edisi 8). Semarang: Badan Penerbit Universitas Diponegoro.

Hakim, R. L. (2017). "Pengaruh Profitabilitas Dan Non Debt Tax Shield Terhadap Struktur Modal (Studi Pada Perusahaan Manufaktur Subsektor Otomotif dan Komponen yang Terdaftar di Bursa Efek Indonesia Periode 2012- 2016)" (Doctoral dissertation, Fakultas Ekonomi dan Bisnis Unpas Bandung).

Hardiyanti, Nia. (2012). "Analisis Pengaruh Insider Ownership, Leverage, Profitability, Firm Size dan Dividen Payout Ratio terhadap Nilai Perusahaan (Studi Pada Perusahaan Manufaktur yang Terdaftar di BEI tahun 2007-2010"). Semarang: Universitas Diponegoro.

Herdirinandasari, S. S., \& Asyik, N. F. (2016). "Pengaruh Ukuran Perusahaan, Profitabilitas, Dan Voluntary Disclousure Terhadap Earning Response Coefficient (ERC)". Jurnal Ilmu dan Riset Akuntansi (JIRA), 5(11).

Kasmir, (2014). "Analisis Laporan Keuangan", Edisi Satu, Cetakan Ketujuh, Raja Grafindo Persada

Mulianti, D. and Ginting, J. (2017). "Analisis Pengaruh Ukuran Perusahaan, Profitabilitas, Timeliness, dan Struktur Modal Terhadap Earnings Response Coefficient Pada Perusahaan Manufaktur yang Terdaftar di Bursa Efek Indonesia Periode20122014"Jakpi.doi: http://dx.doi.org/110.21043/equilibrium.v3i2.1268.

Natsir, R. S. El, (2018). "Pengaruh Leverage Dan Persistensi Laba Terhadap ( Studi Empiris Pada Perusahaan Sektor Properti Dan Real Estate Yang Terdaftar Di Bursa Efek Indonesia 2012-2016 )" Skripsi Oleh: Nama: Recky Syahnal El Natsir Fakultas Ekonomi Universitas Islam Indonesia ', UIN.

Paramita, R. W. D. (2012). "Pengaruh leverage, firm size dan voluntary disclousure terhadap earnings response coeffisient (erc)". WIGA-Jurnal Penelitian Ilmu Ekonomi, 2(2).doi: ISSN: 2088 - 0944.

Pratama, I. and Wiksuana, I. (2016) "Pengaruh Ukuran Perusahaan Dan Leverage Terhadap Nilai Perusahaan Dengan Profitabilitas Sebagai Variabel Mediasi", E-Jurnal Manajemen Universitas Udayana.

Prastowo,Rizqy Dwi. 2017. "Pengaruh Ukuran Perusahaan, Pertumbuhan Perusahaan dan Leverage Terhadap Earnings Response Coefficient." Surabaya: STIE Perbanas Surabaya

Putri, Elsa Widya, et al. (2019). "Pengaruh Growth Opportunity Dan Corporate Social Responsibility Terhadap Earnings Response Coefficient (Studi Pada Perusahaan Manufaktur Sektor Industri Dasar dan Kimia yang Terdaftar di Bursa Efek Indonesia (BEI) Tahun 2013-2017)". Diss. Perpustakaan FEB Unpas. 
Puspita, A. G. (2015). "Pengaruh Penerapan Just In Time Terhadap Efisiensi Biaya Produksi Dan Efektivitas Produksi (Studi Pada PT Sugiura Indonesia)" Doctoral dissertation, Fakultas Ekonomi Unpas.

Sandi, K. U. (2013). Faktor-Faktor yang Mempengaruhi Earnings Response Coefficient. Accounting Analysis Journal, 2(3).

Sari, M. M. (2018). "Pengaruh Leverage, Profitabilitas Dan Voluntary Disclosure Terhadap Earnings Response Coefficient (Erc) (Studi Empiris Pada Perusahaan Manufaktur Yang Terdaftar Di Bei Tahun 2014-2016)", Proceedings, 1(1), pp. 360-371.

Sugiyono, P. D. (2016) "Metode penelitian kuantitatif, kualitatif dan R\&D", Alfabeta, $c v$.

Sutrisna Dewi, N. and Yadnyana, I. K. (2019) "Pengaruh Profitabilitas dan leverage Pada Earning Response Coefficient Dengan Ukuran Perusahaan Sebagai Variabel Pemoderasi".E-Jurnal Akuntansi.

Wulandari, I. and Herkulanus, B. (2015) 'Konservatisme Akuntansi, Good Corporate Governance Dan Pengungkapan Corporate Social Responsibility Pada Earnings Response Coefficient', E-Jurnal Akuntansi

Zulkarnain, Alex. (2015) “Analisis Pengaruh Pengumuman Dividen Terhadap Harga Saham Disekitar Tanggal Ex-Dividen Date”. Diss. Fakultas Ekonomi dan Bisnis 